\title{
Design of intelligent greenhouse automatic control system based on C language Jiaxiong Wen
}

Sichuan Information Technology College

Keywords: Greenhouse automatic control; greenhouse; intelligent; temperature and humidity; light

\begin{abstract}
The greenhouse can effectively improve the yield per unit area of land, out of season limits the growth of plants, based on this, puts forward a set of intelligent greenhouse automatic control system based on $\mathrm{C}$ language design, through the system can be realized in to carry on the accurate control of the greenhouse environment and effectively improve the degree of intelligent greenhouse environment control, increase production of greenhouse cultivation has very important significance.
\end{abstract}

\section{Introduction}

From the point of greenhouse technology development situation in China and abroad, greenhouse control technology development can be divided into three stages, $1^{\text {st }}$ stage is manual control stage, use the traditional instrument and meter to monitor the environment, then manual adjust the relative equipment to control the environment ${ }^{[2-5]}$.

But see from the existing greenhouse automation control system design, most of the control system is designed in a centralized way ${ }^{[9]}$, the intelligent level is low, the greenhouse environmental parameters monitoring is not comprehensive. Considering this background, this thesis propose a design of intelligent greenhouse automatic control system based on $\mathrm{C}$ language.

\section{Basic structure of intelligent greenhouse system}

Greenhouse automatic control system is mainly to maintain the greenhouse environment balance, keep the environment within the setting target and the error of the allowed range ${ }^{[13]}$, please refer to illustrator 1, which show the normal design structure of automatic greenhouse, which normally includes heating equipment, carbon dioxide producing equipment, humidification equipment, ventilation control cabinets, lighting and temperature control cabinet and the central control cabinet etc.

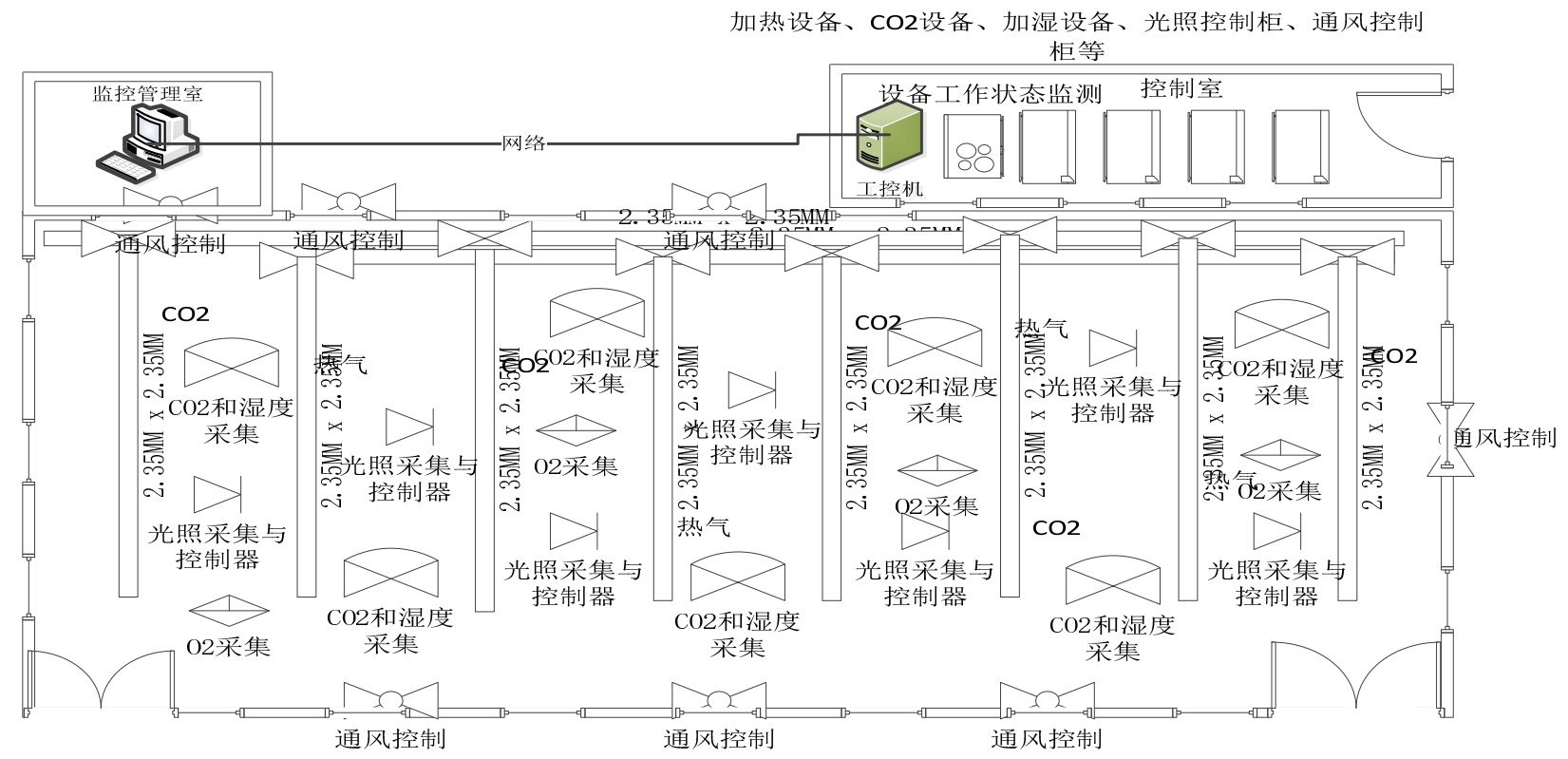

Illustration 1 Design structure of automatic greenhouse 


\begin{tabular}{|l|l|}
\hline 加热设备 & $\begin{array}{l}\text { heating equipment,carbon dioxide producing equipment, and the } \\
\text { central control cabinet etc. }\end{array}$ \\
\hline $\mathrm{CO} 2$ 设备 & carbon dioxide producing equipment \\
\hline 加湿设备 & humidification equipment \\
\hline 光照控制柜 & lighting and temperature control cabinet \\
\hline 通风控制柜 & ventilation control cabinets \\
\hline 监控管理室 & Monitoring and control room \\
\hline 网络 & Network \\
\hline 工控机 & Industrial personal computer \\
\hline 设备工作状态监控 & Equipment working condition monitoring \\
\hline 控制室 & Control room \\
\hline $\mathrm{CO} 2$ 和湿度采集 & CO2\& humidity acquisition \\
\hline 光照采集与控制器 & Lighting acquisition \\
\hline 通风控制 & Ventilation control \\
\hline
\end{tabular}

\section{Intelligent greenhouse automatic control system hardware structure designs}

Based on above analysis of greenhouse automation design structure, we can conclude that the greenhouse automatic control system structure as shown in illustrator 2 , take industrial controller as the core, through the RS485 highway and greenhouse environment data acquisition sensors, control room equipment control network inside the greenhouse to acquire the environment parameter.

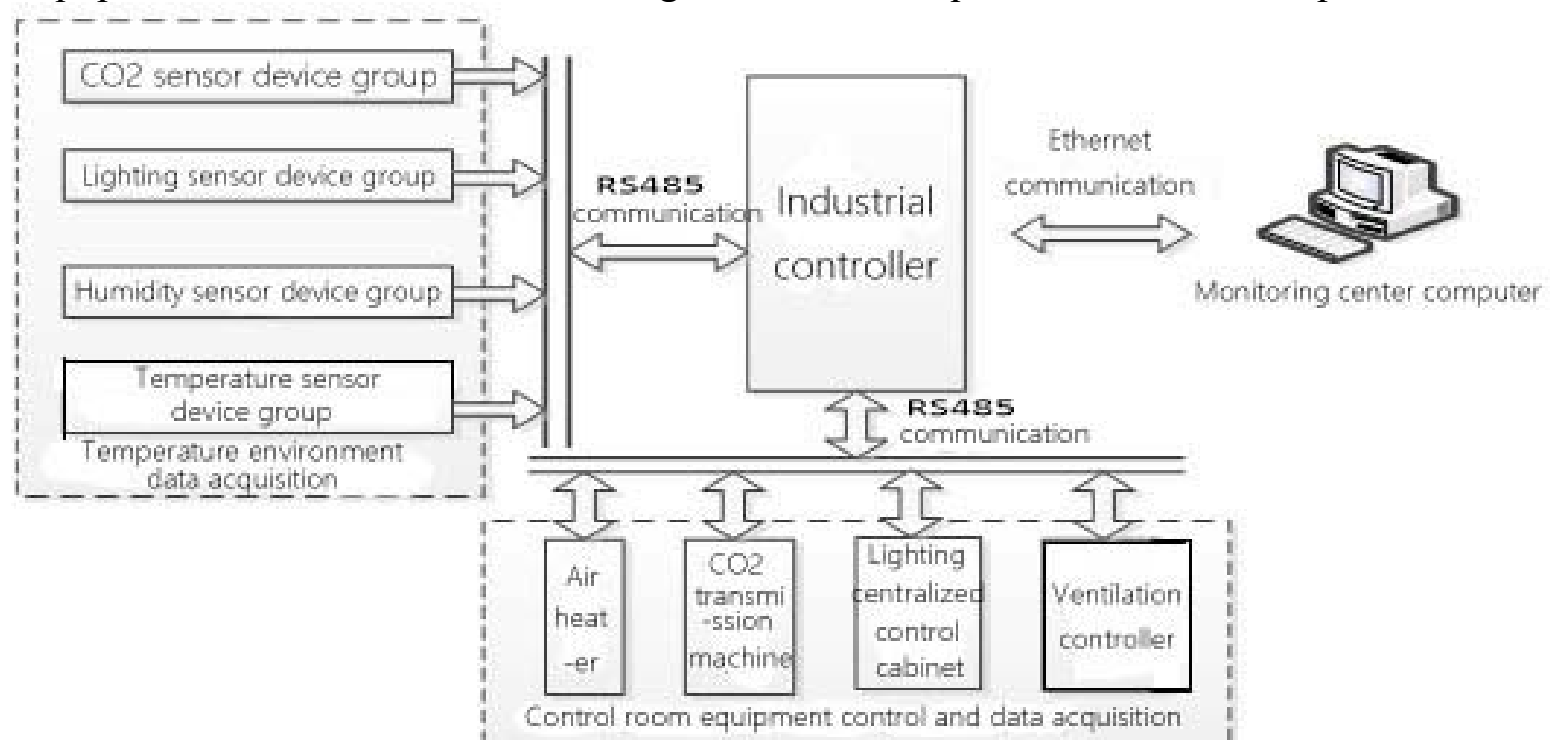

Illustration 2 Intelligent greenhouse automatic control system hardware structure design 


\begin{tabular}{|l|l|}
\hline $\mathrm{CO} 2$ 传感器设备组 & CO2 sensor device group \\
\hline 光照传咸设备组 & Lighting sensor device group \\
\hline 湿度传感器设备组 & Humidity sensor device group \\
\hline 温度传咸设备组 & Temperature sensor device group \\
\hline 室温环境数据采集 & $\begin{array}{l}\text { Temperature environment data } \\
\text { acquisition }\end{array}$ \\
\hline 工业控制器 & Industrial controller \\
\hline 监控中心计算机 & Monitoring center computer \\
\hline 热风机 & Air heater \\
\hline CO2 输送机 & CO2 transmission machine \\
\hline 灯光集中控制柜 & Lighting centralized control cabinet \\
\hline 通风控制器 & Ventilation controller \\
\hline 控制室设备控制与信息采集 & $\begin{array}{l}\text { Control room equipment control and data } \\
\text { acquisition }\end{array}$ \\
\hline
\end{tabular}

\section{Intelligent greenhouse automatic control system software overall structure design}

According to above analysis of intelligent greenhouse automatic control system hardware structure, we can have the conclusion of this thesis, the design of the intelligent greenhouse automatic control system based on $\mathrm{C}$ language software design mainly needs to implement seven modules as RS485 communication, control room equipment acquisition, control room equipment control, sensor information collection, intelligent control, PC based on TCP/IP communication interaction and configuration information processing. System builds on the Linux operating system and the $\mathrm{C}$ program language, the whole software system structure as shown in illustrator 3 .

\begin{tabular}{|c|c|c|c|}
\hline \multicolumn{4}{|c|}{ 智能控制模块 } \\
\hline 传感器信息乐集 & 控制室设备控制 & $\begin{array}{c}\text { 控制室设备信 } \\
\text { 息灾集 }\end{array}$ & \multirow{2}{*}{$\begin{array}{c}\text { 基于TCP/IP上位机 } \\
\text { 通信交互模块 }\end{array}$} \\
\hline \multicolumn{2}{|c|}{ RS485通信模块 } & 配置信息处理 & \\
\hline \multicolumn{3}{|c|}{$\begin{array}{c}\text { LinuxC语言库 } \\
\text { stdio.h/Stdiolib.h/math.h/ string.h/sys/socket.h } \\
\text { sys/types.h/netinet/in.h/netdb.h/unistd.h }\end{array}$} & TCP/IP协议 \\
\hline \multicolumn{4}{|c|}{ Linux操作系统 } \\
\hline
\end{tabular}

Illustration 3 Control system software overall structure design

\begin{tabular}{|c|c|c|c|}
\hline \multicolumn{3}{|c|}{ Intelligent control modules } \\
\hline $\begin{array}{c}\text { Sensor data } \\
\text { collection }\end{array}$ & $\begin{array}{c}\text { control room } \\
\text { equipment control }\end{array}$ & $\begin{array}{c}\text { control room } \\
\text { equipment data } \\
\text { acquisition }\end{array}$ & $\begin{array}{c}\text { PC based on TCP/IP } \\
\text { communication interaction } \\
\text { modules }\end{array}$ \\
\hline $\begin{array}{c}\text { RS485 } \\
\text { communication }\end{array}$ & Configuration information processing \\
\hline \multicolumn{2}{|c|}{ Linux C program language library } & TCP/IP \\
\hline \multicolumn{2}{|c|}{ Linux Running system } \\
\hline
\end{tabular}

\section{System core module design and implementation}

According to above greenhouse automatic control system software overall architecture design we can concluded that the system should include RS485 communication, control room equipment 
acquisition, control room equipment control, sensor information collection, intelligent control, the main function module of system implementation, this section will introduce these two big module design in details.

\subsection{Intelligent control module design and implementation}

Intelligent control module is the core module of the intelligent greenhouse automatic control system based on $\mathrm{C}$ language, it calls information acquisition, equipment control and $\mathrm{PC}$ based on TCP/IP communication interface module to coordinate the whole system to realize the greenhouse environment controlling, guarantee the greenhouse will run smoothly according to various preset environmental parameters, the entire module running processes show as illustrator 4.

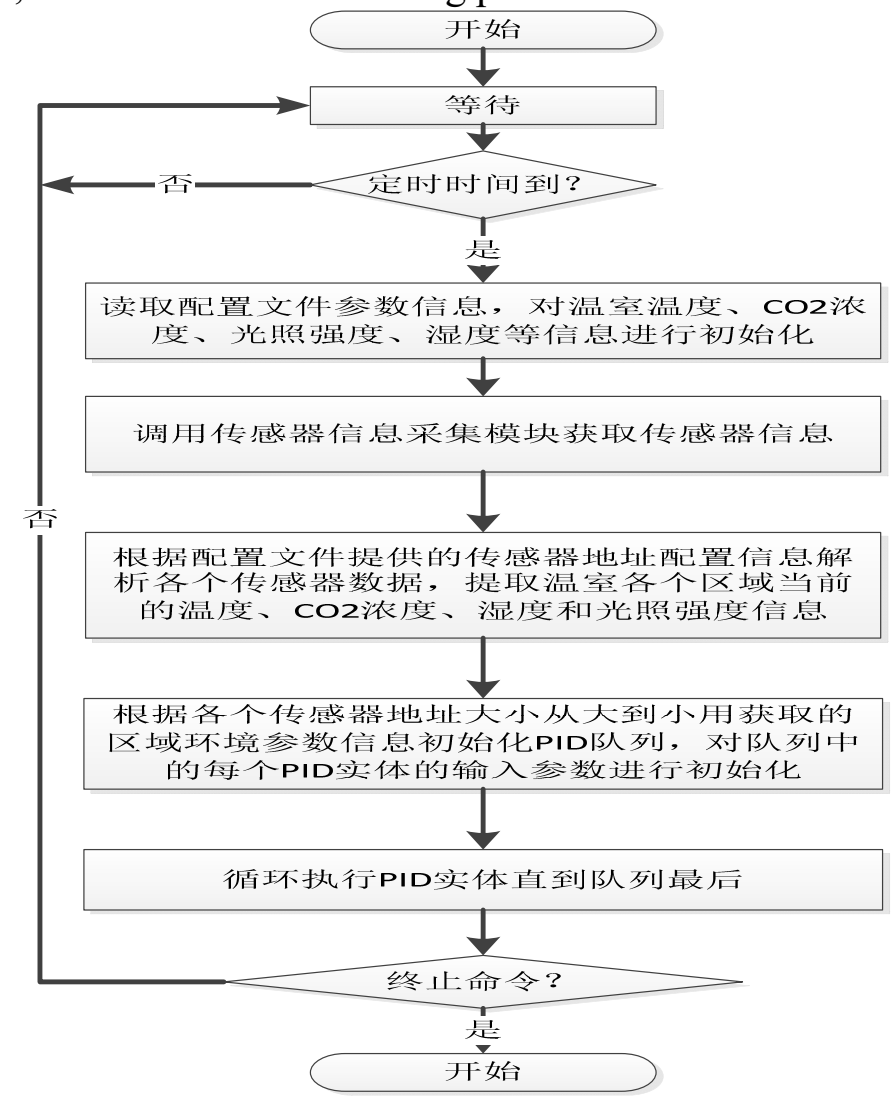

Illustration 4 Intelligent control module design and process 


\begin{tabular}{|c|c|}
\hline 开始 & Start \\
\hline 等待 & Waiting \\
\hline 定时时间到 & Time for Timing \\
\hline $\begin{array}{l}\text { 读取配置文件参数信息, 对室温, } \mathrm{CO} 2 \text { 浓 } \\
\text { 度, 光照轻度, 湿度等信息进行初始化 }\end{array}$ & $\begin{array}{l}\text { Reading configuration files parameter information, } \\
\text { Initialize the room temperature, } \mathrm{CO} 2 \\
\text { concentration, lighting, humidity }\end{array}$ \\
\hline 调用传感器信息采集模块获取传感器信息 & $\begin{array}{l}\text { Call the sensor information acquisition module for } \\
\text { sensor information }\end{array}$ \\
\hline $\begin{array}{l}\text { 根据配置文件提供的传感器地址配置信息 } \\
\text { 解析各个传感器数据, 提取温室各个区域 } \\
\text { 当前的温度, } \mathrm{CO} 2 \text { 浓度, 湿度和光照信息 }\end{array}$ & $\begin{array}{l}\text { According to the configuration file for sensor } \\
\text { address configuration information for each sensor } \\
\text { data analysis, extract the greenhouse } \\
\text { temperature, CO2 concentration, humidity and } \\
\text { light information }\end{array}$ \\
\hline $\begin{array}{l}\text { 根据各个传感器的地址大小从大到小用获 } \\
\text { 取的区域参数信息初始化 PID 队列, 对队 } \\
\text { 列中的每个 PID 实体的输入参数进行初始 } \\
\text { 化 }\end{array}$ & $\begin{array}{l}\text { Arrange Region parameter information from big } \\
\text { size to small size based on the address from each } \\
\text { sensor to initialize the PID queue, initialize each } \\
\text { parameter of PID entity in the queue. }\end{array}$ \\
\hline 循环执行 PID 实体直到队列最后 & Loop PID entity queue until the last one \\
\hline 终止命令 & Terminate the command \\
\hline 结束 & Finish \\
\hline
\end{tabular}

5.2 PC based on TCP/IP communication interaction and control module design and implementation

The principal computer machine based on TCP/IP communication interaction and control module is the interaction control core of the system, and is also the basis for greenhouse system management, the module including two parts, the subordinate computer running on the IPC and the principal computer running on a monitor computer. The subordinate computer is responsible for the reception the control from the principal computer and feedback the whole greenhouse environmental information and equipment operation information to the principal computer. The illustrator 5 as below shows the subordinate computer work process. 


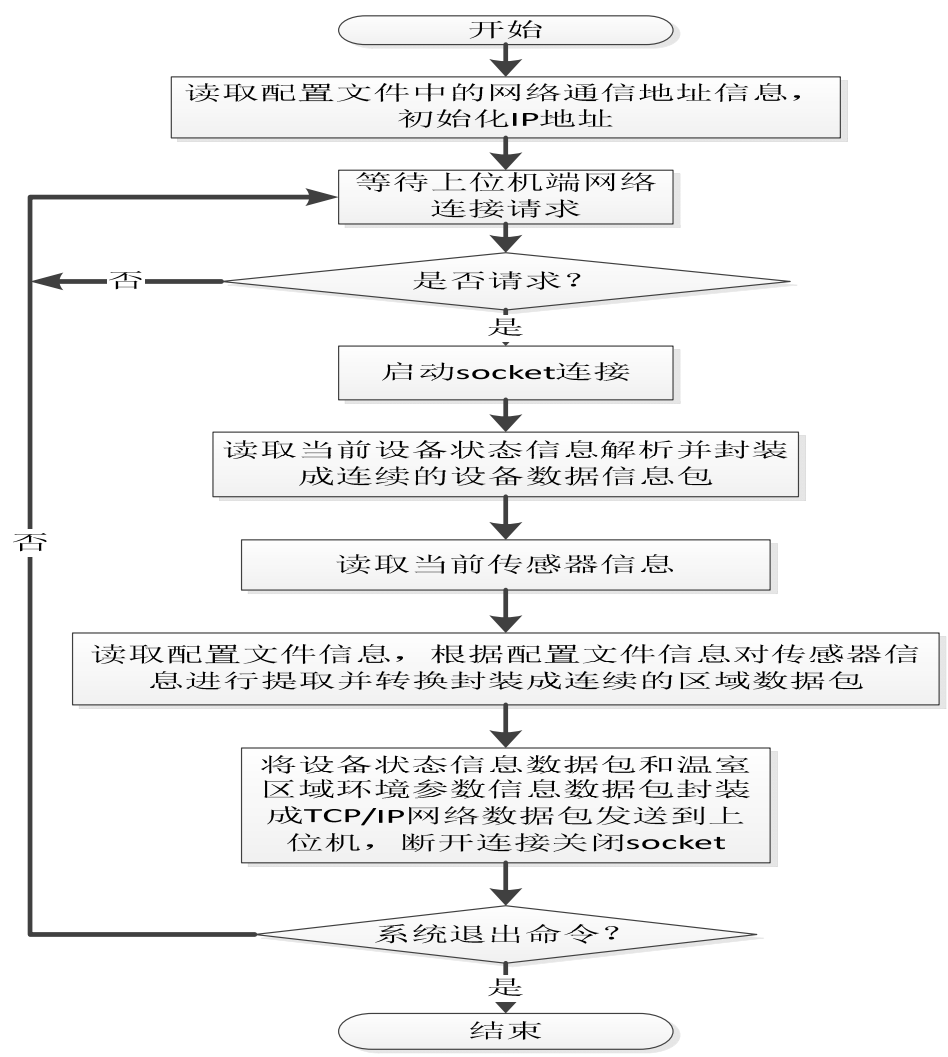

Illustration 5 Subordinate computer with PC based on TCP/IP communication interaction and control module design and implementation

\begin{tabular}{|c|c|}
\hline 开始 & Start \\
\hline $\begin{array}{l}\text { 读取配置文件中的网络通信地址信息, 初始 } \\
\text { 化 IP 地址 }\end{array}$ & $\begin{array}{l}\text { Read network address information in the } \\
\text { configuration file, initialize the IP address }\end{array}$ \\
\hline 等待上位极端网络连接请求 & $\begin{array}{l}\text { Waiting for principal computer network } \\
\text { connection requests }\end{array}$ \\
\hline 是否请求 & Request or not \\
\hline 启动 SOCKET 连接 & Start SOCKET connection \\
\hline 读取当前设备状态信息解析并封装成连续的 & $\begin{array}{l}\text { Read the current equipment state information } \\
\text { analysis and encapsulated into the continuous } \\
\text { data packets }\end{array}$ \\
\hline 读取当前传感器信息 & Read current sensor information \\
\hline $\begin{array}{l}\text { 读取配置文件信息, 根据配置文件信息对传 } \\
\text { 息进行读取并转换封装成连续的区域 } \\
\text { 数据包 }\end{array}$ & $\begin{array}{l}\text { Reads the configuration file information, } \\
\text { according to the configuration file to read and } \\
\text { convert sensor information packets } \\
\text { encapsulated into a continuous area data } \\
\text { package }\end{array}$ \\
\hline $\begin{array}{l}\text { 将设备状态信息数据包和温室区域环境参数 } \\
\text { 誩息数据包封装成 TCP/IP 网络数据包发送到 } \\
\text { 上位机, 断开连接关闭 SOCKET }\end{array}$ & $\begin{array}{l}\text { The equipment state information packet and } \\
\text { greenhouse environment parameter } \\
\text { information encapsulated into a TCP/IP } \\
\text { network packets sent to the PC, disconnect } \\
\text { and close the SOCKET }\end{array}$ \\
\hline 系统退出命令 & Terminate the command \\
\hline 结束 & Finish \\
\hline
\end{tabular}

There are two kinds of design for proposal computer program. $1^{\text {st }}$ one is sending the updated data command to the subordinate computer regularly, request the subordinate computer to feedback the greenhouse environment parameter information and equipment running condition, realize the real-time monitoring. Another design is setting in the program, after setting, the program will 
connected to the subordinate computer to call the initial function to initiate the user interface.

\section{Conclusions}

Greenhouse automatic and intelligent control will improve the greenhouse management efficiency, increase the productivity and also greatly increase the industrialization development of greenhouse cultivation. It is a trend for greenhouse technology development.in the future. So the proposal in this thesis is about design of intelligent greenhouse automatic control system based on $\mathrm{C}$ language. Regarding current intelligent greenhouse design, raise up the hardware and also software structure, explain the design and implementation process of some core module in detail, through testing implementation, proves the intelligent greenhouse automatic control system will realize the centralization management of the greenhouse and automatically control the equipment to maintain the greenhouse environment in a constant condition according to the pre-set parameter, which have very important significance to improve the greenhouse intelligent level and management efficiency.

\section{Reference}

[1] Liuli, Anhong Bao, Shuxing Cao, Xiuzhi hu. "Greenhouse environment Automatic control project design[J]”, Agricultural Mechanization Research, 2013,01:90-93.

[2] Lipeng Bi "Agricultural greenhouses adaptive control system development based on fuzzy neural network [D]" Taiyuan University of Technology,2014

[3] Weibin Zhang "Research and implementation of remote monitoring system of greenhouses based on Zigbee" Northeast Petroleum University,2014

[4] Zouwei Greenhouse Automatic control system design and implementation[D]. Xidian University,2013

[5] Chunlai Liu "Sunlight greenhouse fertigation automation control system introduction[J]". Haihe river water conservancy, 2005,05:58-60.

[6] Jinyu "Industrial control computer application in automation greenhouse control [J]", Industrial control computer, 2000,01:16-18.

[7] Jinjie "design of the agricultural greenhouses control system based on mixed energy" Yanbian University, 2012

[8] Chuanchuan $\mathrm{Tu}$ "Greenhouse environment control system simulation research based on the BP neural network PID control [D]”, Jilin agricultural university,2012

[9] JianchunWng, LiangFu Chen, "Automation control technology application and thinking of the traditional greenhouse[J]”, Anhui Agricultural Science Bulletin, 2015,15:57+90.

[10] Yifei Liu "Greenhouse control system of tomato plant cultured by aeroponics based on LabVIEW[D]" The Chinese academy of agricultural sciences, 2014

[11] Xufei. "The design and implementation of greenhouse intelligent control terminal [D]", Suzhou University, 2014

[12] Zhonghua Wang "Embedded automated greenhouse monitoring system [D]", Inner Mongolia normal university,2013

[13] Jingyu Liang "Intelligent greenhouse environment temperature and humidity measurement and control system research and design [D]", Taiyuan University of Technology,2005

[14] Zhanyuan Bai, Aidong Xu, Chapter 6 of "Automatic monitoring system of greenhouse based on wireless communication technology[J]", Instrument Standardization \& Metrology, 2007,06:27-30. 